\title{
Characterization of biofilm formation in clinical urinary isolates of Staphylococcus aureus from five hospitals in Lagos State, Nigeria
}

\author{
${ }^{1}$ Orjih, C. I., ${ }^{2}$ Ajayi, A., ${ }^{1,3}$ Alao, F. O., ${ }^{1}$ Adeleye, A. I., and ${ }^{* 2,4}$ Smith, S. I. \\ ${ }^{1}$ Department of Microbiology, University of Lagos, Akoka, Nigeria \\ ${ }^{2}$ Molecular Biology and Biotechnology Department, Nigerian Institute of Medical Research, Lagos, Nigeria \\ ${ }^{3}$ Department of Biological Sciences, Bells University of Technology, Ota, Ogun State, Nigeria \\ ${ }^{4}$ Mountain Top University, Lagos-Ibadan Expressway, Ogun State, Nigeria \\ *Correspondence to: stellaismith@yahoo.com
}

\begin{abstract}
:
Background: Biofilm formation by pathogens is of great clinical importance as it mediates persistence and resistance to antibiotics, hence posing difficulty in treatment and management of diseases. The aim of this study was to evaluate the biofilm forming potential of Staphylococcus aureus isolated from urine samples of females with urinary tract infection and to detect the presence of clumping factor (clfA) and intracellular adhesion (icaA) encoding genes.

Methodology: A total of $50 \mathrm{~S}$. aureus were obtained from urine samples of women in five hospitals in Lagos State, Nigeria. Isolates were confirmed by standard biochemical and novobiocin susceptibility tests. The isolates were screened for biofilm formation using three methods; Congo-red agar (CRA), tube, and tissue culture plate (TCP) methods. Detection of clfA and icaA genes was done by PCR.

Results: The Congo red agar method showed that $39(78 \%)$ of the isolates were biofilm producers while 11 (22\%) were non-biofilm producers. However, the tube method indicated that 12 (24\%) were strong biofilm producers, 26 $(52 \%)$ were moderate biofilm producers, and $12(24 \%)$ were non-biofilm producers. The standard TCP assay showed that strong biofilm producers (OD > 0.240) were $13(26 \%)$, moderate biofilm producers were $22(44 \%)$, and weak or non-biofilm producers (OD < 0.120$)$ were $15(30 \%)$. The tube method showed a good correlation with the TCP method for strong biofilm production. Ten (20\%) isolates possessed clfA gene and 31 (62\%) possessed icaA gene.

Conclusion: The ability of $S$. aureus to form biofilm is a key risk factor that can increase morbidity and mortality from infections they cause. Hence, rapid and sensitive phenotypic methods can be used in screening for biofilm formation thereby providing data that can guide therapy and control of the pathogen
\end{abstract}

Keywords: Staphylococcus aureus, Biofilm, Clumping factor, Intracellular adhesion

Received Sept 6, 2020; Revised Oct 22, 2020; Accepted Oct 30, 2020

Copyright 2021 AJCEM Open Access. This article is licensed and distributed under the terms of the Creative Commons Attrition 4.0 International License <a rel="license" href="http://creativecommons.org/licenses/by/4.0/", which permits unrestricted use, distribution and reproduction in any medium, provided credit is given to the original author(s) and the source. Editor-in-Chief: Prof. S. S. Taiwo

\section{Caractérisation de la formation de biofilm dans des isolats urinaires cliniques de Staphylococcus aureus provenant de cinq hôpitaux de l'État de Lagos, Nigéria}

\author{
${ }^{1}$ Orjih, C. I., ${ }^{2}$ Ajayi, A., ${ }^{1,3}$ Alao, F. O., ${ }^{1}$ Adeleye, A. I., et ${ }^{* 2,4}$ Smith, S. I. \\ ${ }^{1}$ Département de microbiologie, Université de Lagos, Akoka, Nigéria \\ ${ }^{2}$ Département de biologie moléculaire et de biotechnologie, Institut nigérian \\ de recherche médicale de Lagos, Nigéria \\ ${ }^{3}$ Département des sciences biologiques, Université de technologie Bells, Ota, Ogun State, Nigeria \\ ${ }^{4}$ Université Mountain Top, autoroute Lagos-Ibadan, État d'Ogun, Nigéria \\ *Correspondance à: stellaismith@yahoo.com
}




\section{Abstrait:}

Contexte: La formation de biofilm par des agents pathogènes est d'une grande importance clinique car elle intervient dans la persistance et la résistance aux antibiotiques, ce qui pose des difficultés dans le traitement et la gestion des maladies. Le but de cette étude était d'évaluer le potentiel de formation de biofilm de Staphylococcus aureus isolé à partir d'échantillons d'urine de femmes atteintes d'une infection des voies urinaires et de détecter la présence de gènes codant pour le facteur d'agglutination (clfA) et l'adhésion intracellulaire (icaA).

Méthodologie: Un total de $50 \mathrm{~S}$. aureus a été obtenu à partir d'échantillons d'urine de femmes dans cinq hôpitaux de l'État de Lagos, au Nigéria. Les isolats ont été confirmés par des tests standard de sensibilité biochimique et à la novobiocine. Les isolats ont été criblés pour la formation de biofilm en utilisant trois méthodes; Méthodes de gélose au rouge Congo (CRA), de tubes et de plaques de culture tissulaire (TCP). La détection des gènes clfA et icaA a été réalisée par PCR.

Résultats: La méthode de l'agar rouge du Congo a montré que 39 (78\%) des isolats étaient des producteurs de biofilm tandis que $11(22 \%)$ n'étaient pas des producteurs de biofilm. Cependant, la méthode du tube a indiqué que $12(24 \%)$ étaient de puissants producteurs de biofilm, 26 (52\%) étaient des producteurs de biofilm modérés et 12 (24\%) n'étaient pas des producteurs de biofilm. Le test TCP standard a montré que les producteurs de biofilm forts (DO $>0,240)$ étaient $13(26 \%)$, les producteurs de biofilm modérés étaient de $22(44 \%)$ et les producteurs de biofilm faibles ou non (DO < 0,120) étaient de $15(30 \%)$. La méthode du tube a montré une bonne corrélation avec la méthode TCP pour une forte production de biofilm. Dix $(20 \%)$ isolats possédaient le gène clfA et 31 (62\%) possédaient le gène icaA.

Conclusion: La capacité de $S$. aureus à former un biofilm est un facteur de risque clé qui peut augmenter la morbidité et la mortalité dues aux infections qu'elles provoquent. Par conséquent, des méthodes phénotypiques rapides et sensibles peuvent être utilisées dans le dépistage de la formation de biofilm, fournissant ainsi des données qui peuvent guider la thérapie et le contrôle du pathogène.

Mots clés: Staphylococcus aureus, Biofilm, Facteur d'agrégation, Adhésion intracellulaire

\section{Introduction:}

Biofilms are communities of bacteria embedded in a self-produced extracellular matrix made of exopolysaccharides (EPSs) containing proteins and some macromolecules such as DNA. They can form on both biotic and abiotic surfaces (1). Studies have shown using scanning electron microscopy (SEM) and other molecular techniques that human tissues and medical implants are colonized by biofilms. Biofilm protects the microorganism from host defences and impedes delivery of antibiotics thereby resulting in the persistence of infections $(2,3)$.

Staphylococcus aureus is an opportunistic pathogen implicated in skin and soft tissue infections. It exists in the nasopharynx, skin, eye, intestine and urogenital tract as normal flora. However, it can breach the skin barriers through the wound or surgical incision and cause infection. Furthermore, it has the ability to adhere to and form a biofilm on tissues or medical indwelling devices (4). S. aureus initially adheres to a solid substrate, after which cell-cell adhesion occurs; and the bacteria then multiply to form a multilayered biofilm encased in EPS.

Biofilm formation involves the production of polysaccharide intercellular adhesin, which depends on the expression of the intercellular adhesion molecule operon (icaADBC) which encodes three membrane proteins (IcaA, IcaD, and IcaC) and one extracellular protein (IcaB). In addition, several surface proteins have been involved in the biofilm formation process in staphylococci including biofilm-associated protein; surface protein G, fibronectin-binding proteins and staphylococcal protein A (5). Biofilm formation by $S$. aureus can lead to delay in re-epithelialization of infected tissues, ultimately increasing healing time. S. aureus biofilms have been associated with chronic wounds such as diabetic foot ulcer, pressure sores and venous ulcers (6). Detachment of matured biofilm of $S$. aureus is a prerequisite for the dissemination of wound infection (7).

In Nigeria, there is paucity of data on studies that characterize biofilm formation in pathogens of clinical origin. Hence this study is aimed at characterizing biofilm formation in clinical $S$. aureus isolates.

\section{Materials and method:}

\section{Study setting and subjects}

The subjects were non-pregnant women presenting with urinary tract infection in five public hospitals; Lagos University Teaching hospital, General Hospital Marina, General Hospital Gbagada, General Hospital Shomolu, and General Hospital Orile-Agege in Lagos State, Nigeria. Samples were collected between February 2015 and April 2017.

\section{Ethical approval}

Ethical approval for this study was obtained from the Human Research and Ethical Committee (HREC) of the Lagos University Teaching Hospital with code number ADM/ 
DCST/HREC/879 and Health Research Ethics Committee of the Gbagada General Hospital with code number GBGH/705/100

\section{Bacterial isolates}

One millilitre of the urine sample was inoculated into $9 \mathrm{~mL}$ of brain heart infusion broth (Oxoid, Basingstoke, UK) and incubated for 24 hours at $37^{\circ} \mathrm{C}$. A loopful of broth culture was then streaked onto mannitol salt agar (Oxoid, Basingstoke, UK) and incubated for 24 hours at $37^{\circ} \mathrm{C}$. Yellow colonies were picked and sub-cultured on nutrient agar to obtain pure colonies. Standard biochemical tests and novobiocin susceptibility test to phenotypically confirm $S$. aureus were carried out according to Cheesbrough (8), with S. aureus ATCC 29213 as quality control strain.

\section{Biofilm formation assay}

Biofilm formation assays were performed according to Mathur et al., (9) and Cavant et al., (10) with slight modifications. All 50 S. aureus isolates were tested by three invitro screening procedures for their ability to form biofilm

\section{Tube method}

Staphylococcus aureus isolates were inoculated into brain heart infusion broth (Oxoid, Basingstoke, UK) and incubated for 24 hours at $37^{\circ} \mathrm{C}$. Thereafter, spent broth were decanted and tubes were washed with phosphate buffered saline $(\mathrm{pH} 7.3)$ and allowed to air dry, and then stained with $0.1 \%$ crystal violet solution. Excess stain was discarded and tubes were washed three times with sterile distilled water and dried. A positive result was indicated by the presence of visible film lining the wall and bottom of the tube. The absence of a film or presence of only a stained ring at the liquid air interface was considered as a negative result. Biofilm forming potential were categorized base on the intensity of film as strong $(+++)$, moderate $(++)$, weak $(+)(9)$. S. aureus ATCC 29213 was used as positive control

\section{Congo-Red Agar (CRA) method}

Suspension of $S$. aureus isolates were inoculated onto brain heart infusion agar (Oxoid, Basingstoke, UK) supplemented with $5 \%$ sucrose and $0.8 \mathrm{~g} / \mathrm{L}$ Congo red. This was done in triplicate and incubated at $37^{\circ} \mathrm{C}$ for 24 to 48 hours. Culture plates that displayed black colonies with a dry crystalline consistency were noted as positive for biofilm formation while plates that had pink colonies with occasional darkening at the center were considered as weak or non-biofilm formers.

\section{Tissue Culture Plate (TCP) method}

Staphylococcus aureus isolates were inoculated into brain heart infusion broth (Oxoid, Basingstoke, UK) supplemented with $2 \%$ sucrose and incubated for 18 hours at $37^{\circ} \mathrm{C}$. A dilution of 1 in 100 with fresh medium was done and $200 \mu \mathrm{L}$ was dispensed into individual wells of sterile 96 well tissue culture plates. Positive control S. aureus ATCC 29213 strain was included in separate wells, while negative control was sterile broth medium. The tissue culture plates were incubated for 18 hours at $37^{\circ} \mathrm{C}$, after which the content of each well was gently removed by tapping the plates. The wells were washed four times with $200 \mu \mathrm{L}$ of phosphate buffer saline $(\mathrm{pH} 7.2)$ to remove free-floating bacteria. Biofilm formed by adherent organisms in plate were fixed with $2 \%$ sodium acetate and stained with $0.1 \%$ crystal violet. Excess stain was washed off gently with deionized water and dye incorporated by the adherent cells was solubilized by adding $200 \mu \mathrm{L}$ of $33 \%$ glacial acetic acid (Merck, Darmstadt, Germany).

The optical density (OD) of each well was determined with an Emax ${ }^{\circledR}$ Plus Microplate Reader (Molecular Devices San Jose, CA) at wave length $570 \mathrm{~nm}$. The experiment was performed in triplicate and repeated three times. Absorbance was calculated by subtracting the $\mathrm{OD}_{570}$ of control from that of the test assays $\mathrm{OD}_{570}$ with mean value determined for each isolate. Data obtained were used to classify $O_{570}$ values $<0.120$ as non-biofilm producers, $\mathrm{OD}_{570}$ values between 0.120-0.240 as moderate biofilm producers, and $\mathrm{OD}_{570}$ values $>0.240$ as strong biofilm producers.

\section{Molecular detection of icaA and clfA genes DNA extraction was done using the method of Suvajdžić et al., (11). PCR was performed by targeting specific primers listed in Table 1. A $20 \mu \mathrm{L}$ PCR reaction containing $4 \mu \mathrm{l}$ (5x) FIREPol master mix [7.5mM $\mathrm{MgCl}_{2}, 1 \mathrm{Mm}$}

Table 1: List of primers targeted to detect icaA and clfA genes

\begin{tabular}{ccc}
\hline Primer & Sequence $\left(5^{\prime}-3^{\prime}\right)$ & Product Size \\
\hline$i c a A-\mathrm{FW}$ & GAGGTAAAGCCAACGCACTC & 151 \\
icaA-RV & CCTGTAACCGCACCAAGTTT & \\
cIfA-FW & ACCCAGGTTCAGATTCTGGCAGCG & 165 \\
IffA-RV & TCGCTGAGTCGGAATCGCTTGCT & $(12)$ \\
\hline
\end{tabular}


dNTPs, $0.4 \mathrm{M}$ Tris- $\mathrm{HCl}, 0.1 \mathrm{M}\left(\mathrm{NH}_{4}\right)_{2} \mathrm{SO}_{4}, 0.1 \%$ Tween-20, FIREPol DNA Polymerase) (Solis BioDyne, Estonia)], 0.6 $\mu \mathrm{L}$ forward primer, $0.6 \mu \mathrm{L}$ reverse primer, $4 \mu \mathrm{L}$ DNA template and $10.8 \mu \mathrm{L}$ nuclease free water, was carried out in a Master cycler (Eppendorf AG, Hamburg, Germany). Amplification conditions consist of initial DNA denaturation at $95^{\circ} \mathrm{C}$ for $5 \mathrm{~min}$, followed by 35 cycles of denaturation at $95^{\circ} \mathrm{C}$ for $30 \mathrm{~s}$, annealing at $45^{\circ} \mathrm{C}$ for clfA and $54^{\circ} \mathrm{C}$ for Ica $A$ for $30 \mathrm{~s}$ and extension at $72^{\circ} \mathrm{C}$ for $2 \mathrm{~min}$, followed by a final extension at $72^{\circ} \mathrm{C}$ for $10 \mathrm{~min}$. Amplification products were analysed by electrophoresis at $100 \mathrm{~V}$ for $60 \mathrm{~min}$ in $2 \%$ agarose gel stained with ethidium bromide and visualized under ultraviolet trans-illuminator (Cleaver Scientific Ltd). A 100bp DNA ladder (Solis BioDyne, Estonia) was used as a molecular weight marker.

\section{Statistical analysis}

Microsoft Excel (Microsoft Cooperation, 2013 USA) was used to generate graphics and determine percentages

\section{Results:}

The three phenotypic biofilm characterization methods used yielded varying results. The CRA method indicated that 39 $(78 \%)$ of the isolates were biofilm producers while $11(22 \%)$ of the isolates were non-biofilm producers as shown in Fig 1 . However, the tube method indicated that $12(24 \%)$ were strong biofilm producers, 26 (52\%) were moderate biofilm producers and 12 (24\%) were non-biofilm producers. The standard TCP assay showed that strong biofilm producers (OD > $0.240)$ were $13(26 \%)$, moderate biofilm producers were 22 (44\%) and weak or non-biofilm producers (OD $<0.120)$ were $15(30 \%)$. The tube method showed a good correlation with the TCP for strong biofilm producers as shown in Fig 2.

Despite the phenotypic display of biofilm formation by the $S$. aureus isolates, only $10(20 \%)$ harboured clumping factor encoding gene (clfA) while the intracellular adhesion encoding gene (icaA) was detected in 31 (62\%) isolates as shown in Fig 3.

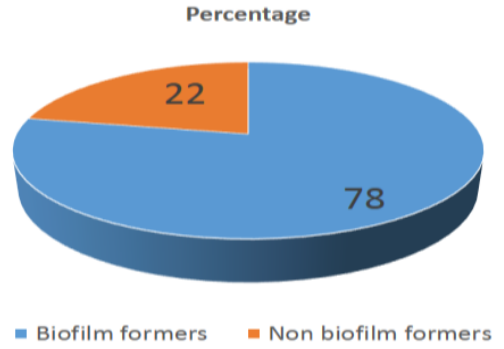

Fig 1: Frequency (\%) of biofilm formation among Staphylococcus aureus isolates by Congo red agar method

A

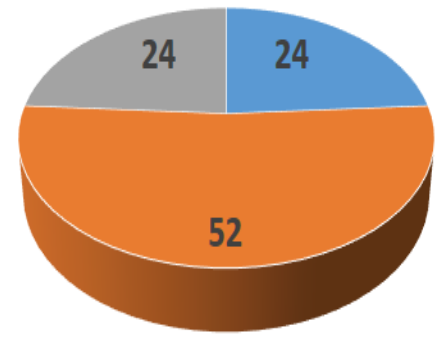

- Strong Biofilm formers " Moderate Biofilm formers " Weak Biofilm formers
B

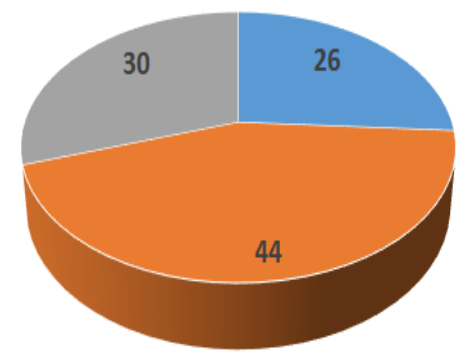

- Strong Biofilm formers " Moderate Biofilm formers Weak Biofilm formers

Fig 2: Frequency (\%) of strong, moderate and weak biofilm formation among Staphylococcus aureus isolates by the tube $(A)$ and TCP $(B)$ methods 


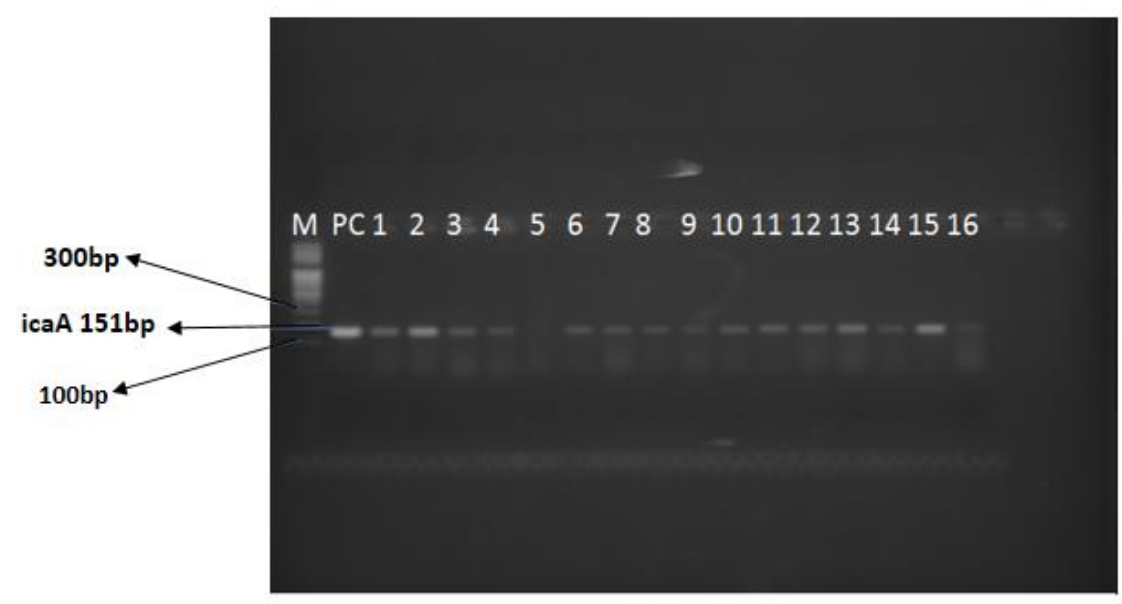

Lane M: 100bp molecular marker, Lane PC: Positive control, Lane 1-16 with the exception of Lane 5 are positive for icaA gene

Fig 3: Agarose gel image showing the $151 \mathrm{bp}$ icaA gene detected in Staphylococcus aureus isolates

\section{Discussion:}

Biofilm forming $S$. aureus has been linked to life threatening infections that defies antimicrobial therapy due to resistance, which encourage persistence and easy dissemination (12). In this study, the TCP assay method revealed that $13(26 \%)$ of the S. aureus isolates screened were strong biofilm formers, $44 \%$ were moderate biofilm formers, and $30 \%$ were weak or non-biofilm formers. This is similar to the findings of Mathur et al. (9) who reported $14.47 \%, 39.4 \%$, and $46.0 \%$ as strong, moderate and weak $S$. aureus biofilm formers respectively. This method gives the best discrimination between strong, moderate and non-biofilm formers as it used cut-off values.

Although the tube method correlated well with the TCP strong biofilm formers in this study, weak formers were difficult to discriminate from non-biofilm formers. The tube method detected slightly lower number of strong biofilm formers with $24 \%$, which was lower in comparison to the TCP method with $26 \%$. However, the observation of Flemming et al., (13) showed that TCP method detected $69 \%$ of biofilm formers, whereas, TM detected only $36 \%$. The authors further opined that this method could discriminate between strong and moderate biofilm formers since it is a quantitative method.

In this study, CRA detected $78 \% \mathrm{~S}$. aureus isolates that were biofilm formers and $22 \%$ non-biofilm formers. However, this is at variance with previous observations made by Mathur et al., (9) and Taj et al., (14) who reported very low percentage $5.3 \%$, and $3.4 \%$ of biofilm formers respectively by the CRA method. In a similar study by Sharvari and Chitra (15), a higher percentage $(25.3 \%)$ was reported. The higher percentage reported in our study using the CRA method could be attributed to a modification in the preparation of the CRA in our laboratory by filter sterilization of the Congo red before addition to the molten autoclaved brain heart infusion agar.

Clumping factor A (clfA) has been reported to mediate adhesion to fibrinogen thereby enhancing the formation of biofilm in S. aureus. In the report of Wolz et al., (16), staphylococcal clfA cloned into Streptococcus gordonii and Lactococcus lactis which lack surface adhesion potentially gained the ability and were able to cause endocarditis in an animal model. PCR assay of clfA in this study revealed that $24 \%$ of the $S$. aureus isolates possessed the gene. In a similar study, Nourbakhsh and Namvar (17) reported a slightly higher carriage rate $(41.4 \%)$ of clfA gene in $S$. aureus isolated from nosocomial infection in Isfahan Iran. As opposed to the low occurrence of clfA genes in our isolates, majority $(62 \%, \mathrm{n}=31)$ of them carried icaA gene. Kifaya et al., (18) reported that all $S$. aureus isolates assayed for icaA gene were positive for the gene and they all phenotypically formed biofilm, which agrees with our study where all 31 isolates carrying ica $A$ gene phenotypically formed biofilm. The correlation of biofilm formation and the possession of icaA gene was also reported by Namvar et al., (12).

\section{Conclusion:}

Biofilm formation by microbial pathogens remains a great threat in the healthcare sector because infections caused by them are 
associated with increased morbidity and mortality, as well as contributing to significant financial burden on the economy. Hence, the use of nanoparticles that have been shown to compromise integrity or destroy biofilms, may be explored in tackling the challenges of biofilm forming pathogens.

\section{References:}

1. Yuyama, K. T., Wendt, L., Surup, F., et al. Cytochalasans act as inhibitors of biofilm formation of Staphylococcus aureus. Biomolecules. 2018; 8: 129

2. Lister, J. J., and Horswill, A. R. Staphylococcus aureus biofilm: Recent developments in biofilm dispersal. Front. Cell Infect Microbiol. 2014; 4: 178.

3. Geoghegan, J. A., Monk, I. R., O'Gara, J. P., and Foster, T. J. Subdomains N2N3 of fibronectin binding protein A mediate Staphylococcus aureus biofilm formation and adherence to fibrinogen using distinct mechanisms. J Bacteriol. 2013; 195: 2675-2683.

4. Khan, S. Isolation of Shigella species and their resistance patterns to a panel of fifteen antibiotics in mid and far western region of Nepal. Asian Pac J Trop Dis. 2014; 4: 30-34.

5. Lucy, F. The Extracellular Matrix of Staphylococcus aureus Biofilms Comprises Cytoplasmic Proteins That Associate with the Cell Surface in Response to Decreasing pH. MBio. 2014; 5: 1667-1674.

6. Peleg, I. Epidemiological trends and patterns of antimicrobial resistance of Shigella spp. isolated from stool cultures in two different populations in Southern Israel. Diagn Microbiol Infect Dis. 2013; 78: 201-320.

7. Hurlow, J., Couch, K., Laforet, K., Bolton, L., Metcalf, D., and Bowler, P. Clinical biofilms: a challenging frontier in wound care. Adv Wound Care J. 2015; 4 (5): 295-301.

8. Cheesbrough, M. Staphylococcus aureus. In: District laboratory practice in tropical countries. Part 2. $2^{\text {nd }}$ Edition. Cambridge University Press, London 2006: 157-158.

9. Mathur, T., Singhal, S., Khan, S., Upadhyay, D. J., Fatma, T., and Rattan, A. Detection of biofilm formation among the clinical isolates of Staphylococci: an evaluation of three different screening methods. Indian J Med Microbiol. 2006; 24 (1): 25-29.

10. Chavant, P., Gaillard-Martinie, B., Talon, R., Hebraud, M., and Bernardi, T. A new device for rapid evaluation of biofilm formation potential by bacteria. J Microbiol Methods. 2007; 68: 605-612.

11. Suvajdžić, B., Teodorović, V., Vasilev, D., et al. Detection of icaA and icaD genes of Staphylococcus aureus isolated in cases of bovine mastitis in the republic of Serbia. Acta VeterinariaBeograd. 2017; 67 (2): 168-177.

12. Namvar, A. E., Asghari, B., Ezzatifar, F., Azizi, G., and Lari, A. R. Detection of the intercellular adhesion gene cluster (Ica) in clinical Staphylococcus aureus isolates. GMS Hyg Infect Contr. 2013; 8 (1): 03.

13. Flemming, H. C., Wingender, J., Szewzyk, U., Steinberg, P., Rice, S. A., and Kjelleberg, S. Biofilms: an emergent form of bacterial life. Nat Rev Microbiol. 2016; 14 (9): 563-575.

14. Taj, Y., Essa, F., Aziz, F., and Kazim, S. U. Study on biofilm-forming properties of clinical isolates of Staphylococcus aureus. J Infect Dev Ctries. 2012; 6 (5): 403-409.
15. Sharvari, S., and Chitra, P. Evaluation of different detection methods of biofilm formation in clinical isolates of Staphylococci. Int J Pharm Biol Sci. 2012; 3 (3): 724-733.

16. Wolz, C., Goerke, C., Landmann, R., Zimmerli, W., and Fluckiger, U. Transcription of Clumping Factor A in Attached and Unattached Staphylococcus aureus In Vitro and during Device-Related Infection. Infect. Immun. 2002; 70(6): 2758-2762

17. Nourbakhsh, F., and Namvar, A. E. Detection of genes involved in biofilm formation in Staphylococcus aureus isolates. GMS Hyg Infect Contr. 2016; 11: 263.

18. Kifaya, A., Walaa, Q., and Ziad, A. Screening of genes encoding adhesion factors and biofilm production in methicillin resistant strains of Staphylococcus aureus isolated from Palestinian patients. BMC Genomics. 2019; 20: 578. 